\title{
8.5. НАЦИОНАЛЬНЫЙ СУВЕРЕНИТЕТ В УСЛОВИЯХ ФИНАНСОВОЙ ИНТЕГРАЦИИ И УНИФИКАЦИИ
}

Морозов В.А., д.э.н., профессор, кафедра философии и методологии экономики, Экономический фракультет

\author{
Московский государственный университет им. М.В. Ломоносова, г. Москва
}

Настоящая работа рассматривает влияние неолиберализма на финансовую либерализацию, инициированную развитыми странами, трансформировавшую индустриальный капитализм в интегрированный финансовый капитализм. Исследовано содержание государственного суверенитета по трехуровневой системе. Рассмотрен характер влияния глобализации финансового капитализма на фринансовый суверенитет, включая существенный рост издержек осуществления денежно-кредитной политики и уязвимость внутренних финансовых условий к внешним воздействиям. Для сохранения финансового суверенитета стран предложены пути защиты от влияния глобализации финансового капитализма.

\section{Литература}

1. Бушуева Н.В. Финансовая глобализация: содержание и проблемы [Текст] / Н.В. Бушуева, А.А. Аношкин ; под ред. Ю.С. Руденко, Л.Г. Руденко. - М. : Изд-во Московского ун-та им. С.Ю. Витте, 2016. - С. 129-139.

2. Глобализация в Китае [Электронный ресурc]. - URL : http://yandex.ru/clck/jsredir? bu=35xz4d\&fro=yandex.ru

3. Глобализация и интеграционные процессы в Азиатско-Тихоокеанском регионе [Текст] / под ред. Т.Я. Хабриевой. - М. : ИНФРА-М, 2016. - 332 с.

4. Железняк А.В. Влияние глобализации на суверенитет государства [Текст] / А,В. Железняк, И.В. Скуратов // Тр. ОИ МГЮА. - 2015. - Вып. 26. - С. 12-17.

5. Кузнецов А.В. Финансовая глобализация и национальный суверенитет [Текст] / А.В. Кузнецов // США и Канада: экономика, политика, культура. - 2012. - Вып. 2. - С. 22-37.

6. Трифонов Д.С. Финансовая глобализация как современный этап интернационализации мирового хозяйства Д.С. Трифонов // Вестн. Саратовского гос. соц.-экон. ун-та. - 2014. - №5. - С. 45-48.

7. Финансовая глобализация и государственный суверенитет [Электронный ресурс]. $-\quad U R L$ http://yandex.ru/clck/jsredir?bu=9v7l7b\&from=yandex.ru

8. Экономический суверенитет и суверенная экономика [Текст] / под ред. М.Ю. Осипова. -- М. : МАКС Пресс, 2013. - 320 c.

\section{Ключевые слова}

Финансовый суверенитет; финансовый капитал; национальная безопасность; фринансовый капитализм; глобализация.

\section{Морозов Владимир Александрович}

\section{РЕЦЕНЗИЯ}

Статья В.А. Морозова посвящена рассмотрению влияния неолиберализма на финансовую либерализацию, инициированную развитыми странами, трансформировавшую индустриальный капитализм в интегрированный финансовый капитализм. Произведено развернутое исследование содержания государственного суверенитета по трехуровневой системе.

Автор справедливо замечает, что в последнее время давление финансового капитала и финансового капитализма остро сказывается на задачах национального финансового суверенитета ряда стран (особенно развивающихся). Сегодня понятия национального суверенитета, по сути, приравниваются к национальной финансовой безопасности.

Основной заслугой работы является обоснование фактора глобализации финансового капитализма в увеличении системных рисков для мировой финансовой системы и мировой экономики, когда создастся атмосфера глобального финансового кризиса. Рассмотрен характер влияния глобализации финансового капитализма и показаны пути предотвращения этого суверенными государствами в случаях координации финансовой политики, в том числе при делегировании части полномочий по финансовому регулированию как официальным, так и неофициальным международным финансовым организациям (Международный валютный фронд и Базельский комитет по банковскому надзору). Автор отмечает, что такое делегирование регулирующих полномочий является посягательством на фринансовые суверенные полномочия. Это особенно важно для развивающихся стран, так как они не находятся на равных правах в этих международных организациях.

Важно подчеркнуть рассмотрение вопроса автором о влиянии глобализации финансового капитализма на существенном росте издержек осуществления денежно-кредитной политики для монетарных властей при одновременном сокращении выгод. В статье показан остающийся суверенный потенциал государств в части осуществления таких стратегий, как фиксированные обменные курсы и контроль над движением капитала. В этом контексте показана история возникновения вопроса в ряде государств и отдельных территорий. Автор приводит мнения и выводы ведущих ученых (включая Нобелевских лауреатов) по данной тематике.

Автор в работе делает акцент на то, что развивающиеся страны должны принять меры по стимулированию устойчивого роста инновационной реальной экономики в целях укрепления фринансового суверенного потенциала. Сильная инновационная реальная экономика может не только защитить развивающиеся страны от экономических и финансовых рисков, но и помочь им укрепить свой финансовый суверенный потенциал, поскольку сильная реальная экономика может обеспечить суверенное государство ресурсами, необходимыми для осуществления финансовой политики. Приводятся примеры развития и укрепления сегодня экономик ведущих стран Европы и Америки. Значительное место в статье отводится трансформации китайской и индийской экономики. В заключение автор отмечает, что за последние четверть века воздействие неолиберализма в финансах как фактора экономического развития было сильно преувеличено.

Представленная В.А. Морозовым статья «Национальный суверенитет в условиях фринансовой интеграции и унификации» отвечает всем необходимым требованиям для публикации в печати, включая журнал: «Аудит и финансовый анализ».

Казаков В.Н., д.э.н., профессор кафедры фрилософии и методологии экономики Экономического фракультета Московского государственного университета им. М.В. Ломоносова, г. Москва.

DOI 10.38097/AFA.2020.21.51.029 